Łukasz Szternel ${ }^{1}$, Magdalena Krintus ${ }^{1}$, Katarzyna Bergmann"1, Tadeusz Dereziński², Grażyna Sypniewska ${ }^{1}$

${ }^{1}$ Department of Laboratory Medicine, Nicolaus Copernicus University, Collegium Medicum in Bydgoszcz, Poland

2Outpatient Clinic "Esculap" in Gniewkowo, Poland

\title{
Occurrence of hyperlipidemia in relation to body mass index in school children aged 9-11
}

\section{Corresponding author:}

Łukasz Szternel

Department of Laboratory Medicine

Collegium Medicum,

Nicolaus Copernicus University

9 Sklodowskiej-Curie Street

85-094 Bydgoszcz, Poland

Phone: +485258540 46

Fax: +48525853603

E-mail: lukaszszternel@wp.p
Folia Medica Copernicana 2015; Volume 3, Number 4, 170-175 10.5603/FMC.2015.0013 Copyright (C) 2015 Via Medica ISSN 2300-5432

\begin{abstract}
Background. There is a link between lipid disorders and body mass and the occurrence of cardiovascular diseases. This study aimed at establishing the prevalence of lipid abnormalities in relation to body mass in children aged 9-11.

Materials and methods. The study involved 232 presumably healthy school children aged 9-11. Fasting venous blood samples were taken from every child to assess the lipid profile: total cholesterol (TC), LDL cholesterol (LDL-C, direct measurement), HDL cholesterol (HDL-C) and triglycerides (TG). Anthropometric measurements were performed including height and weight, followed by calculating the body mass index (BMI) by using an online "OLAF" calculator.

Results. The prevalence of hypercholesterolemia and an elevated concentration of LDL-C in the group of children was high and equaled $51.1 \%$ and $34.6 \%$, respectively. Hypertriglyceridemia in the respective age groups of 9 and $10-11$ years was found to be: $41.6 \%$ and $27.7 \%$. Only in $9.5 \%$ of children the level of HDL-C was lower than optimal. The percentage of overweight was two-fold higher among boys than in girls (13.6 V. $6.9 \%$ ), similarly the percentage of obesity was higher in boys compared with that in girls (15.5 v. 10.3\%). Conclusions. In school children aged 9-11 the dominant and most frequent lipid abnormality, not associated with an increased body mass, was hypercholesterolemia followed by hypertriglyceridemia. Overweight and obesity were strongly related to gender and much more frequent among boys. There should be more attention paid to dyslipidemia and body weight already in childhood in the context of health policy and prevention.

Key words: hyperlipidemia, children, BMI, obesity, overweight
\end{abstract}

Folia Medica Copernicana 2015; 3 (4): 170-175

\section{Introduction}

The concentration of total cholesterol (TC) and low-density lipoprotein cholesterol (LDL-C) fraction during the first week after birth is higher compared with fetal life and gradually increases till the second year of life $[1,2]$. During the next years of life the lipid profile remains stable until the age of puberty. To avoid biased results, lipid screening should not be performed at puberty due to the hormonal changes. Screening for lipid profile in children aged 9-11 is considered an optimal tool for an early identification of subclinical atherosclerosis. It can help children diagnosed with genetically determined hypercholesterolemia by implementing proper medical treatment. Children aged 2-11 with already diagnosed familial hypercholesterolemia ( $\mathrm{FH}$ ) should have lipid profile tests performed fasting (10-12 $\mathrm{h}$ after the last meal). Laboratory test should be done twice within 2-3 weeks for establishing the average concentrations of the two measurements. Whether the lipid screening is pertinent or not is still being widely disputed. However, American Academy of Pediatrics (AAP), in its latest recommendations, emphasized the need for screening of lipids in children (aged 2-10) being at risk of cardiovascular disease (CVD). According to AAP, the risk factors that indicate the need for early lipid tests in children are: BMI (body mass index) $>85$ percentile, BP (blood pressure) $>95$ percentile; family history of CVD diseases: $\leq 55$ years (for women) and $\leq 65$ years (for men) and also familial dyslipidemia, diabetes and exposure to tobacco smoke $[1,3,4]$. 
Table 1. Distribution of children under study according to age and gender

\begin{tabular}{llllll}
\hline Age (years) & Girls & \multicolumn{3}{c}{ Boys } & Total \\
\cline { 2 - 6 } & Number & $\mathbf{( \% )}$ & Number & $\mathbf{( \% )}$ & Number \\
\hline 9 & 38 & 49.4 & 39 & 50.6 & 77 \\
10 & 52 & 55.3 & 42 & 44.7 & 94 \\
11 & 30 & 49.2 & 31 & 50.8 & 61 \\
Total & $\mathbf{1 2 0}$ & $\mathbf{5 1 . 7}$ & $\mathbf{1 1 2}$ & $\mathbf{4 8 . 3}$ & $\mathbf{2 3 2}$
\end{tabular}

Table 2. Currently accepted cut-off values of lipids for children and teens (according to NCEP — National Cholesterol Education Program) [1]

\begin{tabular}{lllll}
\hline Parameter & $\begin{array}{l}\text { Age category } \\
\text { (years) }\end{array}$ & $\begin{array}{l}\text { Acceptable values } \\
{[\mathbf{m g} / \mathbf{d L}]}\end{array}$ & $\begin{array}{l}\text { Borderline limits } \\
{[\mathbf{m g} / \mathbf{d L}]}\end{array}$ & $\begin{array}{l}\text { High values } \\
{[\mathbf{m g} / \mathbf{d L}]}\end{array}$ \\
\hline TC & $0-19$ & $<170$ & $170-199$ & $\geq 200$ \\
HDL-C & $0-24$ & $>45$ & $35-45$ & - \\
LDL-cholesterol & $0-19$ & $<110$ & $110-129$ & $\geq 130$ \\
TG & $0-9$ & $<75$ & $75-99$ & $\geq 100$ \\
& $10-19$ & $<90$ & $90-129$ & $\geq 130$ \\
\hline
\end{tabular}

TC — total cholesterol; HDL-C — high-density lipoprotein cholesterol; LDL-C — low-density lipoprotein cholesterol; TG — triglycerides

Cardiovascular diseases represent a major cause of diseases in adulthood in most developing countries. One of the most common and dangerous causes of CVD is a growing epidemic of overweight and obesity. According to WHO (World Health Organization), each year 2.8 million people die as a result of overweight or obesity [5]. Moreover, together with increasing BMl the risk of CVD as well as type 2 diabetes increases. In 2008 , according to $\mathrm{WHO}$, $35 \%$ of people worldwide were considered overweight based on $\mathrm{BMl} \geq 25 \mathrm{~kg} / \mathrm{m}^{2}[5,6]$. Problems with overweight and obesity in adulthood derive from the same problems in childhood. Many overweight children will become obese adolescents and, consequently, obese adults with an already higher risk of CVD. Although CVDs are very rare in children, certain risk factors observed in childhood can increase the risk of such diseases in adulthood. Atherosclerotic changes were found in post-mortem studies of children and youth. Early atherosclerotic lesions in the vessels were described as "fatty streaks" [7, 8]. They may already appear in the fetal blood vessels. Findings from the Polish study "OLAF" conducted between $2007-2011$ have shown that $18.6 \%$ of boys and $14.5 \%$ of girls aged $7-18$ were overweight or obese [9]. According to the "OLAF" project overweight and obesity affect approximately $22 \%$ of boys and $18 \%$ of girls in primary schools; this prevalence is slightly lower in secondary schools (15\% of boys and $12 \%$ of girls, respectively). The study conducted by WHO clearly shows that the rate of mortality increases with an increase of obesity rate $[5,10]$.

The aim of this study was to evaluate the occurrence of hyperlipidemia in school children aged 9-11 in the
Kuyavian-Pomeranian region. Additionally, a relationship between body mass index and lipid abnormalities was assessed.

\section{Subjects, materials and methods}

The study involved 232 school children (aged 9-11) from the Kuyavian-Pomeranian voivodeship. The subjects were divided according to gender. There were 120 girls (51.7\%) and 112 boys (48.3\%). The number of subjects taking part in the study divided according to age and sex is presented in Table 1. Fasting blood samples were collected from every child for biochemical analysis. Laboratory tests were done for 231 subjects to measure particular components of the lipid profile: total cholesterol (TC), HDL and LDL cholesterol as well as triglyceride levels (TG) with the use of clinical chemistry analyzer ABX Pentra 400 (Horiba Medical); LDL-C was analyzed using a direct method. The lipid levels were not measured in one boy aged 10 due to an insufficient sample volume. Reference ranges or cutoff values for individual components of the lipid profile in children are shown in Table 2 in accordance with The National Heart, Lung and Blood Institute (NHLBI) guidelines [11]. Anthropometric measurements (height and weight) were conducted on 226 children (116 girls and 110 boys) by using a medical digital scale with stadiometer. Body mass index (BMI) percentiles of 226 children were calculated by means of an online $\mathrm{BMI}$ calculator (based on the OLAF project). The BMI percentiles classification was performed in accordance 
with the up-to-date guidelines of the International Obesity Task Force (IOTF); underweight: BMI < 5; overweight: $\mathrm{BMI} \geq 85$ and < 95; obesity: BMI $\geq 95$ [12]. The study was approved by the Collegium Medicum Bioethics Committee (at the Nicolaus Copernicus University). Parental consent forms were obtained before the study.

\section{Results}

The study group (232 children) was divided into three age categories: group 1 (9 yrs), group 2 (10 yrs) and group 3 (11 yrs). Table 3 shows the average concentrations of lipid parameters according to age in children under study. The highest average TC concentration, $173 \pm 23 \mathrm{mg} / \mathrm{dL}$, was observed in group 1 .
The highest TC value, $315 \mathrm{mg} / \mathrm{dL}$, was recorded in group 2. In none of the age groups the mean LDL-C concentration was above the accepted cut-off value of $110 \mathrm{mg} / \mathrm{dL}$, however, in the group of 10-year-old children the highest individual value of $253 \mathrm{mg} / \mathrm{dL}$ was recorded. In all three age groups the average HDL-C concentration was higher than the cut-off value of $45 \mathrm{mg} / \mathrm{dL}$. The lowest individual HDL-C was observed in the group of 9 -year-old children $(29 \mathrm{mg} / \mathrm{dL})$. Mean TG level only in the children aged 9 was slightly higher $(80 \pm 45 \mathrm{mg} / \mathrm{dL})$ than the accepted cut-off. The highest individual TG value of $277 \mathrm{mg} / \mathrm{dL}$ was observed in the group of children aged 10.

The average values of TC, HDL-C, LDL-C and TG divided by sex and age are presented in Table 4 and 5 . Elevated average TC concentrations, independent

Table 3. Average concentrations of lipid parameters in $\mathrm{mg} / \mathrm{dL}$ according to age in children under study (mean $\pm \mathrm{SD}$; $\min -\max )$

\begin{tabular}{lllll}
\hline Age (years) & TC & LDL-C & HDL-C & TG \\
\hline $9(\mathrm{n}=77)$ & $173 \pm 23$ & $104 \pm 21$ & $60 \pm 13$ & $80 \pm 45$ \\
& $(132-243)$ & $(67-168)$ & $(29-107)$ & $(27-244)$ \\
$10(\mathrm{n}=94)$ & $172 \pm 31$ & $102 \pm 29$ & $59 \pm 13$ & $83 \pm 45$ \\
& $(112-315)$ & $(53-253)$ & $(30-96)$ & $(32-277)$ \\
$11(\mathrm{n}=61)$ & $166 \pm 31$ & $96 \pm 26$ & $61 \pm 16$ & $79 \pm 35$ \\
& $(115-239)$ & $(23-154)$ & $(33-146)$ & $(29-190)$ \\
\hline
\end{tabular}

TC — total cholesterol; HDL-C — high-density lipoprotein cholesterol; LDL-C — low-density lipoprotein cholesterol; TG — triglycerides

Table 4. Average concentrations of lipids in $\mathrm{mg} / \mathrm{dL}$ in girls according to age

\begin{tabular}{lllll}
\hline Age (years) & TC & LDL-C & HDL-C & TG \\
\hline 9 & $172 \pm 21$ & $108 \pm 18$ & $57 \pm 11$ & $83 \pm 49$ \\
& $(118-218)$ & $(54-140)$ & $(29-88)$ & $(28-244)$ \\
10 & $172 \pm 32$ & $102 \pm 31$ & $60 \pm 11$ & $78 \pm 31$ \\
& $(112-315)$ & $(53-253)$ & $(39-90)$ & $(33-180)$ \\
11 & $167 \pm 34$ & $92 \pm 29$ & $64 \pm 20$ & $83 \pm 34$ \\
& $(115-239)$ & $(23-154)$ & $(33-146)$ & $(44-188)$ \\
All & $\mathbf{1 7 1} \pm \mathbf{2 9}$ & $\mathbf{1 0 1} \pm \mathbf{2 7}$ & $\mathbf{6 0} \pm \mathbf{1 4}$ & $\mathbf{8 1} \pm \mathbf{3 8}$ \\
& $(\mathbf{1 1 2 - 3 1 5 )}$ & $\mathbf{( 2 3 - 2 5 3 )}$ & $\mathbf{( 2 9 - 1 4 6 )}$ & $\mathbf{( 2 8 - 2 4 4 )}$
\end{tabular}

TC — total cholesterol; HDL-C — high-density lipoprotein cholesterol; LDL-C — low-density lipoprotein cholesterol; TG — triglycerides

Table 5. Average concentrations of lipids in boys according to age

\begin{tabular}{lllll}
\hline Age (years) & TC & LDL-C & HDL-C & TG \\
\hline 9 & $174 \pm 27$ & $101 \pm 24$ & $63 \pm 14$ & $76 \pm 41$ \\
& $(133-243)$ & $(67-168)$ & $(36-107)$ & $(27-205)$ \\
10 & $173 \pm 31$ & $103 \pm 27$ & $57 \pm 15$ & $89 \pm 57$ \\
& $(121-245)$ & $(63-179)$ & $(30-96)$ & $(32-277)$ \\
11 & $165 \pm 28$ & $99 \pm 23$ & $59 \pm 11$ & $75 \pm 37$ \\
& $(116-230)$ & $(55-143)$ & $(40-78)$ & $(29-191)$ \\
All & $\mathbf{1 7 1} \pm \mathbf{2 9}$ & $\mathbf{1 0 1} \pm \mathbf{2 5}$ & $\mathbf{6 0} \pm \mathbf{1 4}$ & $\mathbf{8 1} \pm \mathbf{4 7}$ \\
& $(\mathbf{1 1 6 - 2 4 5 )}$ & $\mathbf{( 5 4 - 1 7 9 )}$ & $\mathbf{( 3 0 - 1 0 7 )}$ & $\mathbf{( 2 7 - 2 7 7 )}$
\end{tabular}

TC — total cholesterol; HDL-C — high-density lipoprotein cholesterol; LDL-C — low-density lipoprotein cholesterol; TG — triglycerides 
Table 6. Distribution of body mass in children included in the study according to BMI percentiles

\begin{tabular}{|c|c|c|c|c|c|c|}
\hline \multirow{2}{*}{$\begin{array}{l}\text { Age } \\
\text { (years) }\end{array}$} & \multirow{2}{*}{ Sex } & \multicolumn{5}{|c|}{ BMI - category [percentiles] } \\
\hline & & {$[N] / \%$} & $\begin{array}{l}\text { Low body mass } \\
{[B M I<5]}\end{array}$ & $\begin{array}{l}\text { Optimal body mass } \\
{[B M I \geq 5} \\
\text { and }<85]\end{array}$ & $\begin{array}{l}\text { Overweight } \\
{[B M I \geq 85} \\
\text { and }<95]\end{array}$ & $\begin{array}{l}\text { Obesity } \\
{[\geq 95]}\end{array}$ \\
\hline \multirow[t]{2}{*}{9} & Girls & & $2(5.4)$ & $27(73.0)$ & $2(5.4)$ & $6(16.2)$ \\
\hline & Boys & $=\overparen{\circ}$ & $2(5.1)$ & $24(61.5)$ & $7(18.0)$ & $6(15.4)$ \\
\hline \multirow[t]{2}{*}{10} & Girls & Zై & $4(8.0)$ & $39(78.0)$ & $3(6.0)$ & $4(8.0)$ \\
\hline & Boys & 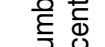 & $4(10.0)$ & $22(55.0)$ & $4(10.0)$ & $10(25.0)$ \\
\hline \multirow[t]{2}{*}{11} & Girls & 2 & $2(6.9)$ & $22(75.9)$ & $3(10.3)$ & $2(6.9)$ \\
\hline & Boys & & $0(0)$ & $26(83.9)$ & $4(12.9)$ & $1(3.2)$ \\
\hline
\end{tabular}

$\mathrm{BMI}$ - body mass index

Table 7. Percentage of increased lipid concentrations and frequency of overweight and obesity in children under study

\begin{tabular}{|c|c|c|c|c|c|c|}
\hline \multirow[t]{2}{*}{ Sex } & \multicolumn{2}{|l|}{ BMI [percentiles] } & \multicolumn{4}{|c|}{$\%$ of increased individual lipid concentrations } \\
\hline & $\begin{array}{l}\text { BMI }<95 \\
\text { and } \geq 85 \\
\text { (overweight, \%) }\end{array}$ & $\begin{array}{l}\text { BMI } \geq 95 \\
\text { (obesity, \%) }\end{array}$ & $\begin{array}{l}\mathrm{TC} \\
\geq 170 \mathrm{mg} / \mathrm{dL} \\
(\%)\end{array}$ & $\begin{array}{l}\text { LDL-C } \\
\geq 110 \mathrm{mg} / \mathrm{dL} \\
(\%)\end{array}$ & $\begin{array}{l}\text { HDL-C } \\
<45 \mathrm{mg} / \mathrm{dL} \\
(\%)\end{array}$ & $\begin{array}{l}\text { TG } \\
0-9 \text { yrs: > } 75 \mathrm{mg} / \mathrm{dL}(\%) \\
10-19 \text { yrs: }>90 \mathrm{mg} / \mathrm{dL}(\%)\end{array}$ \\
\hline Girls & 6.9 & 10.3 & 51.7 & 35.8 & 9.2 & 32.6 \\
\hline Boys & 13.6 & 15.5 & 50.5 & 33.3 & 9.8 & 36.9 \\
\hline All & 10.2 & 12.8 & 51.1 & 34.6 & 9.5 & 34.7 \\
\hline
\end{tabular}

BMI — body mass index; TC — total cholesterol; HDL-C — high-density lipoprotein cholesterol; LDL-C — low-density lipoprotein cholesterol; $\mathrm{TG}$ - triglycerides

of gender, were found in groups of 9- and 10-year-old children. Similarly, elevated mean TG concentrations that seemed to be gender-independent were recorded in the group of children aged 9 .

Table 6 presents absolute values and percentages for individual body mass categories according to BMI percentiles by age and sex. Following the BMI percentile values, the occurrence of overweight in girls was lower in all age groups compared with boys. However, the occurrence of obesity was much lower only in 10-yearold girls (8.0 v. $25.0 \%$, respectively). Interestingly, the percentage of obesity in 11-year-old boys was more than two-fold lower in comparison with girls of the same age (3.2 v. $6.9 \%$, respectively).

The occurrence of overweight and obesity and the percentage of increased lipid values among girls and boys are presented in Table 7. In girls aged 9-11 the proportion of overweight was much lower than in boys (6.9 v. $13.6 \%)$. Similarly, the proportion of obesity was lower in girls compared with boys (10.3 v. $15.5 \%$ ).

Hypercholesterolemia was found in $51.1 \%$ of all children and decreased HDL-C ( $<45 \mathrm{mg} / \mathrm{dL})$ in $9.5 \%$ of all children. Abnormal TG concentrations were recorded more frequently in boys than in girls $(36.9$ v. $32.6 \%$, respectively). In girls with increased body mass ( $\geq 85$ percentile) the percentage of hypercholesterolemia or hypertriglyceridemia, merely, was $25 \%$ and $10 \%$, re- spectively. Interestingly, in girls with normal body mass the percentage of hypercholesterolemia only was higher (35.1\%). Among boys with an increased body mass the percentage of hypercholesterolemia and hypertriglyceridemia only was as follows: $18.8 \%$ and $21.9 \%$. Similarly, in boys with normal body mass the percentage of hypercholesterolemia only was almost two-fold higher (34.5\%).

\section{Discussion}

Epidemiological studies conducted in many countries (including Poland) show that the number of children with excessive body mass and accompanying dyslipidemia has increased significantly [13]. This condition is usually caused by improper diet and a lack of physical activity. An abnormal lipid profile in children under 2 years of age is most commonly related to a genetic mutation which defines such a disorder as familial hypercholesterolemia $(\mathrm{FH})$ [13]. It is estimated that over $30 \%$ of obese preschoolers and almost $80 \%$ of obese teenagers are likely to become obese adults [14]. Obesity among 6-year-old children puts them at 25 percent risk of developing obesity in adulthood [15]. Obesity in 12-year-old children increases the risk of being an obese adult by 75 percent $[14,16]$. In our study con- 
ducted within the Kuyavian-Pomeranian voivodeship we have found that the occurrence of overweight and obesity among 9-11-year-old school children was $23 \%$. It shows that almost every fourth child had excessive body mass. These data are comparable to the results from the Institute of Mother and Child (Poland) showing that nearly $22 \%$ of children aged between 11-12 are overweight including obesity $[17,18]$. Epidemiological data indicate that in Poland, in the school year 20092010 , the percentage of obese and overweight children aged between $6-19$ was $16.4 \%$ (18.7\% boys and $14.3 \%$ girls) [9]. In 2010, the Institute of Mother and Child conducted the study in five different voivodeships in Poland which revealed that children aged 9 had a prevalence of obesity equal to $19 \%$ among girls and $17 \%$ among boys. According to the "OLAF" study, carried out in Poland in 2007-2010, in children aged 7-18, the prevalence of overweight and obesity equals $18.6 \%$ among boys and $14.5 \%$ among girls. Altogether in the "OLAF" study the prevalence of overweight and obesity in children was $20 \%$ [7]. In our study, the occurrence of overweight and obesity in 9-11-year-old girls was also lower than among boys. Gender differences related to obesity occurrence observed by us are more similar to those found in the "OLAF" study.

Hypercholesterolemia was the dominant lipid abnormality in children under this study. It should be stressed that the presence of hypercholesterolemia was not significantly associated with an increased body mass in children. It was identified in more than half of all the children (51.1\%). The average TC concentration was the highest in the youngest children, whereas the lowest was recorded in the 11-year-olds. Similarly, the highest average LDL-C was found in the group of 9-year-old children and the lowest was observed in the 11-yearolds. In the Kuyavian-Pomeranian voivodeship in 2006-2011 , the lipid profile was assessed for the "Regional Programme of Overcoming Children and Adolescence Obesity" in children aged 2-18. Altogether, 300 children participated in the study. The occurrence of hypercholesterolemia was $39.0 \%$ (32/82) in 7-10-year-olds and $40.3 \%$ (54/134) in 11-14-year-olds. The total prevalence of hypercholesterolemia in the "Programme of Overcoming Children and Adolescence Obesity" among children aged $2-18$ was $34 \%$ (102/300). In our study performed in 2015 in the same region, the occurrence of hypercholesterolemia in 9-11-year-old children was higher [16, 19, 20].

While hypercholesterolemia seemed to occur more frequently among girls, hypertriglyceridemia, the second characteristic feature of lipid abnormalities in children aged 9-11, was found more frequently in boys. As our study indicates, in the Kuyavian-Pomeranian voivodeship the prevalence of overweight and obesity is not decreasing but, on the contrary, it is on the increase in comparison with the same studies carried out in the last few years. Considering this phenomenon to be just a harmless temporary state is in fact dangerous for the health and life of obese children. Excessive body mass leads to a whole range of disorders such as metabolic syndrome, diabetes mellitus type 2 and hypertension that until now were only seen in adults. Parents must be aware that although overweight and obesity seem relatively harmless, they carry a huge risk for their children's health, such as lipid abnormalities observed in this study. Health-promoting policy should embrace the introduction of a set of appropriate preventive and medical actions in all areas of child care. Pathological conditions of blood vessels in the form of fatty streaks can even disappear with the change of lifestyle, and consequently delay or preclude the development of atherosclerotic changes [3, 15, 12, 21, 22].

\section{Conclusion}

In school children 9-11 years of age the dominant and most frequent lipid abnormality, not always associated with an increased body mass, was hypercholesterolemia followed by hypertriglyceridemia. Overweight and obesity were strongly related to gender and much more frequent among boys. There should be more attention paid to dyslipidemia and body weight already in childhood in the context of health policy and prevention.

\section{Acknowledgements}

The authors would like to thank Mrs Bogumila Kierul and nurses from Outpatient Clinic in Gniewkowo for their great help during blood collection.

\section{References}

1. Myśliwiec M., Walczak M., Małecka-Tendera E et al. Management in familial hypercholesterolemia in children and adolescents. Position of the Lipid Expert Forum. Kardiologia Polska 2013; 10: 1099-1105.

2. Goldberg AC, Hopkins PN, Toth PP et al. Familial Hypercholesterolemia: Screening, diagnosis and management of pediatric and adult patients. Clinical guidance from the National Lipid Association Expert Panel on Familial Hypercholesterolemia. J Clin Lipidol 2011; 5: 133-140

3. Werner B. Badania stężenia cholesterol u dzieci. Swiatlekarza.pl 2013.

4. Peter O. Kwiterovich Jr. Recognition and management of dyslipidemia in children and adolescents. J Clin Endocrinol Metab 2008; 93 : 4200-4209.

5. Global Health Observatory data. (http://www.who.int/gho/ncd/risk factors/obesity_text/en/).

6. Grabiński M. Hyperlipidemias in Children. Adv Clin Exp Med 2007; 1: 165-170.

7. Grajda A, Kułaga Z, Gurzkowska B et al. Regional differences in the prevalence of overweight, obesity and underweight among polish children and adolescents. Med Wieku Rozwoj 2011; 15: 258-265.

8. Kavey RE, Allada V, Daniels SR et al. Cardiovascular risk reduction in high-risk pediatric patients: A scientific statement from the American Heart Association Expert Panel on Population and Prevention 
Science; the Councils on Cardiovascular Disease in the Young Epidemiology and Prevention, Nutrition. Physical Activity and Metabolism, High Blood Pressure Research, Cardiovascular Nursing, and the Kidney in Heart Disease; and the Interdisciplinary Working Group on Quality of Care and Outcomes Research Endorsed by the American Academy of Pediatrics. Circulation 2006 114: 2710-2738.

9. Kułaga Z, Różdżyńska A, Palczewska l et.al. Percentile charts of height, body mass and body mass index in children and adolescents in Poland - results of the OLAF study. Standardy Medyczne 2010; 7: 690-700.

10. Sypniewska G. Laboratory assessment of cardiometabolic risk in overweight and obese children. Clin Bioch 2015; 48: 370-376.

11. Expert Panel on Integrated Guidelines for Cardiovascular Health and Risk Reduction in Children and Adolescents: Summary Report. http://www.nhlbi.nih.gov/health-pro/guidelines/current/cardiovascular-health-pediatric-guidelines/summary.

12. International Obesity Task Force. European Union Platform Briefing Paper. Brussels, 15 March2005 (http://ec.europa.eu/health/ph determinants/life_style/nutrition/documents/iotf_en.pdf).

13. Koton-Czarnecka M. Nadciśnienie i dyslipidemia u dzieci — problem coraz większy. 2015 (http://www.kardiolog.pl/publikacje/34846).

14. Instytut Matki i dziecka. Otyłość dzieci i młodzieży. Poradnik dla rodziców. (www.imid.med.pl)

15. Przybylska D, Kurowska M, Przybylski P. Obesity and overweight in the adolescent population. Hygeia Public Health 2012; 47: 28-35.
16. Urząd Marszałkowski Województwa Kujawsko-Pomorskiego. Program edukacyjno-leczniczy na rzecz zmniejszania częstości występowania nadwagi i otyłości u dzieci i młodzieży w województwie kujawsko-pomorskim 2013

17. Mazur A. The epidemiology of childhood overweight and obesity on the World, in Europe and in Poland. Przegląd Medyczny Uniwersytetu Rzeszowskiego i Narodowego Instytutu Leków w Warszawie. 2011; 2: 158-163.

18. The epidemiology of childhood overweight and obesity on the World, in Europe and in Poland. According to report of HBSC 2010. http://www. gis.gov.pl/ckfinder/userfiles/files/Nadwaga\%20i\%20oty\%C5\%820\%C5\%9B\%C4\%87\%20dzieci\%20i\%20m\%C5\%82odzie\%C5\%BC\%20 dane.pdf.

19. Wolnicka K. Epidemia nadwagi i otyłości wśród dzieci i młodzieży w Polsce (/pl/epidemia-nadwagi-i-otylosci-wsrod-dzieci-i-mlodziezyw-polsce-2/)

20. Nawarycz T, Ostrowska-Nawarycz L. Otyłość brzuszna u dzieci i młodzieży- doświadczenia lódzkie. Endokrynologia, Otyłość, Zaburzenia Przemiany Materii 2007; 3: 1-8.

21. Bryl W, Hoffman K, Miczke A et al. Otyłość w młodym wieku - epidemiologia, konsekwencje zdrowotne, konieczność prewencji. Przew Lek 2006; 9: 91-95.

22. Ministerstwo Zdrowia, POL-HEALTH. Narodowy program zapobiegania nadwadze i otyłości oraz przewlekłym chorobom niezakaźnym poprzez poprawę żywienia i aktywności fizycznej na lata 2007-2011. Warszawa 2007 